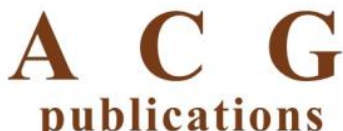

Rec. Nat. Prod. 14:5 (2020) 312-318

records of natural

products

\title{
New Spectinabilin and Hexadienamide Derivatives from Streptomyces sp. S012
}

\author{
Zhiqiang Zhang $\oplus^{1}$, Xiaochun Zhang $\oplus^{1}$, Qianjin Kang $\oplus^{2}$ and \\ Chunhua Lu(B) $1, *$
}

\begin{abstract}
${ }^{1}$ Key Laboratory of Chemical Biology (Ministry of Education), School of Pharmaceutical Sciences, Shandong University, Jinan 250012, China

${ }^{2}$ State key Laboratory of Microbial Metabolism, Shanghai Jiaotong University, Shanghai, 200240,
\end{abstract} China

(Received December 24, 2019; Revised February 19, 2020; Accepted March 05, 2020)

\begin{abstract}
A new spectinabilin derivative (1) and a new hexadienamide derivative (3), together with (-)spectinabilin (2) and sarmentosamide (4), were isolated from Streptomyces sp. S012. Their structures were elucidated on the basis of spectroscopic analysis, including ${ }^{1} \mathrm{H},{ }^{13} \mathrm{C} \mathrm{NMR},{ }^{1} \mathrm{H}-{ }^{1} \mathrm{H}$ COSY, HSQC, HMBC, NOESY and HRESIMS. Their antibacterial activity was also evaluated in this study.
\end{abstract}

Keywords: Spectinabilin; hexadienamide; Streptomyces sp. S012; spectral data. @ 2020 ACG Publications. All rights reserved.

\section{Introduction}

Streptomyces sp. S012 was isolated from the rhizosphere soil of Nanjing Zhongshan Botanical Garden. Previously, a series of streptovaricins with diverse bioactivities were isolated from this strain $[1,2]$. Herein, a new spectinabilin derivative (1) and a new hexadienamide (3) together with (-)spectinabilin (2) and sarmentosamide (4) are reported including their isolation, structural elucidation and antimicrobial activities. Compounds $\mathbf{1}$ and $\mathbf{2}$ are unusual nitroaryl-substituted polyene polyketides, while $\mathbf{3}$ and $\mathbf{4}$ are rare hexadienamide derivatives [3, 4]. Prior to this study, only a few spectinabilin and hexadienamide analogues have been reported, such as spectinabilin $[2,5]$, aureothin $[6,7]$, SNF4435 C and D [8-10], arabilin [11], sarmentosamide [3], erythrococcamides A-E [12] and $N$ isobutyl-6-(2-thienyl)-2E,4E-hexadienamide [13].

\section{Materials and Methods}

\subsection{General Experimental Procedure}

Optical rotation was measured on a Perkin-Elmer 341 polarimeter (Anton Paar GmbH, Graz, Austria). UV spectra were recorded on a UV-1800 UV spectrophotometer (Shimadzu, Kyoto, Japan).

* Corresponding author: E-Mail: ahua0966@sdu.edu.cn Phone: +86-531-88382108 Fax: +86-531-88382108 
NMR spectra were recorded on a Bruker DRX-600 MHz and DRX-400 MHz NMR spectrometer (Bruker Daltonics Inc., Billerica,Massachusetts) with tetramethylsilane (TMS) as an internal standard. HRESIMS was measured on an LTQ-Orbitrap XL. Sephadex LH-20 was obtained from the GE Amersham Biosciences (Pis-cataway, New Jersey). Reversed-phase C-18 (RP-18) silica gel for column chromatography (CC) was obtained from Merck (Darmstadt, Germany). HPLC separations were mainly performed on Waters 1525 Binary HPLC Pump equipped with Waters 996 Photodiode Array Detector using Agilent Eclipse XDB-C18 column $(5 \mu \mathrm{m}, 9.4 * 250 \mathrm{~mm})$. Silica gel $\mathrm{GF}_{254}$ for thin-layer chromatography (TLC) was purchased from Qingdao Marine Chemical Ltd (Qingdao, China).

\subsection{Fermentation and Isolation}

The Streptomyces sp. S012 strain was cultured for $12 \mathrm{~d}$ on ISP3 agar plates $(40 \mathrm{~L})$ at $28{ }^{\circ} \mathrm{C}$. At the end of fermentation, the agar cultures were diced and extracted three times with EtOAc-MeOH $(4: 1, v / v)$ at room temperature. The organic solvents were evaporated and the extract was partitioned between $\mathrm{ddH}_{2} \mathrm{O}$ and EtOAc $(1: 1, v / v)$. The EtOAc extract was further partitioned between 95\% aqueous $\mathrm{MeOH}$ and petroleum ether (PE) to afford $\mathrm{MeOH}$ extract $(9.0 \mathrm{~g})$. The $\mathrm{MeOH}$ extract was subjected to CC over Sephadex LH-20 eluted with $\mathrm{MeOH}$ to obtain Fr.1 and Fr.2 (8.0 g). Fr.2 was further fractionated by MPLC (145 g RP-18 silica gel; 30\%, 50\%, 70\% MeOH and 100\% MeOH, $1 \mathrm{~L}$ each, respectively) to afford Fr.2a-2d. Fr.2a was chromatographed over Sephadex LH-20 (120 g; $\mathrm{MeOH}$ ) to afford Fr. 2al-2a4. Fr.2a4 was subjected to reversed-phase HPLC (Waters 1525 instrument; Agilent Eclipse XDB-C18 column ID: $5 \mu \mathrm{m}, 9.4 * 250 \mathrm{~mm}$ ) eluted with $20 \% \mathrm{CH}_{3} \mathrm{CN}(4$ $\mathrm{mL} / \mathrm{min}, \mathrm{UV} 254 \mathrm{~nm})$ to obtain $4\left(t_{\mathrm{R}} 13.0 \mathrm{~min}, 8.0 \mathrm{mg}\right)$.

Fr. $2 c$ was fractionated by CC over Sephadex LH-20 and MPLC over RP-18 silica gel to afford Fr.2c1-Fr.2c7. Fr.2c2 was further purified by HPLC (Waters 1525 instrument; column ID: $9.4 * 250$ $\mathrm{mm}, 5 \mu \mathrm{m})$ eluted with $55 \%$ and $70 \% \mathrm{CH}_{3} \mathrm{CN}(4.0 \mathrm{~mL} / \mathrm{min}$, UV $254 \mathrm{~nm})$ to obtain $3\left(t_{\mathrm{R}} 22 \mathrm{~min}, 7.2\right.$ $\mathrm{mg}$ ) and $1\left(t_{\mathrm{R}} 10.6 \mathrm{~min}, 5.2 \mathrm{mg}\right.$, UV $\left.254 \mathrm{~nm}\right)$, respectively. By the similar procedure, $2\left(t_{\mathrm{R}} 19.5 \mathrm{~min}\right.$ $5.4 \mathrm{mg}$, UV $254 \mathrm{~nm}$ ) was purified from Fr. $2 d$ by HPLC eluted with $60 \% \mathrm{CH}_{3} \mathrm{CN}$.

Compound 1: Pale yellow oil; $[\alpha]]^{25}-239.50(c 0.1, \mathrm{MeOH}) ;{ }^{1} \mathrm{H}$ and ${ }^{13} \mathrm{C}$ NMR data see Table 1 and Table S1. UV/Vis $(\log \varepsilon): \lambda_{\max } 212$ (4.10), 267 (3.92), 296 (3.61) nm; HRESIMS $(\mathrm{m} / \mathrm{z}): 955.4301$ $[2 \mathrm{M}+\mathrm{H}]^{+}$(Calcd. for $\left.\mathrm{C}_{56} \mathrm{H}_{63} \mathrm{~N}_{2} \mathrm{O}_{12}{ }^{+}, 955.4376\right)$.

(-)-Spectinabilin (2): Pale yellow oil; $[\alpha]^{25} \mathrm{D}-40\left(c 0.1, \mathrm{CHCl}_{3}\right) ;{ }^{1} \mathrm{H}$ and ${ }^{13} \mathrm{C}$ NMR data see Table 1 and Table S2. UV/Vis $(\log \varepsilon): \lambda_{\max } 258(3.36) \mathrm{nm}$; HRESIMS $(\mathrm{m} / \mathrm{z}): 478.2168[\mathrm{M}+\mathrm{H}]^{+}($Calcd. for $\mathrm{C}_{28} \mathrm{H}_{32} \mathrm{NO}_{6}{ }^{+}, 478.2222$ ).

Compound 3: Pale yellow oil; $[\alpha]{ }^{25} \mathrm{D}-66.7(c \mathrm{c} .1, \mathrm{MeOH}) ;{ }^{1} \mathrm{H}$ and ${ }^{13} \mathrm{C}$ NMR data see Table 2 and Table S3. UV/Vis $(\log \varepsilon): \lambda_{\max } 216$ (3.44), 259 (3.50), 296 (2.91) nm; HRESIMS $(\mathrm{m} / \mathrm{z}): 238.0702[\mathrm{M}+$ $\mathrm{H}]^{+}$(Calcd. for $\left.\mathrm{C}_{13} \mathrm{H}_{20} \mathrm{NO}_{3}{ }^{+}, 238.1438\right)$.

Sarmentosamide (4): Pale yellow oil; $[\alpha]^{25} \mathrm{D}-174.5(c 0.2, \mathrm{MeOH}) ;{ }^{1} \mathrm{H}$ and ${ }^{13} \mathrm{C}$ NMR data see Table 2 and Table S4. UV/Vis (loge): $\lambda_{\max } 211$ (4.36), 224 (4.39), 264 (3.93) nm; ESIMS ( $\left.\mathrm{m} / \mathrm{z}\right): 223.4$ $[\mathrm{M}+\mathrm{H}]^{+}$and $245.5[\mathrm{M}+\mathrm{Na}]^{+}$.

\subsection{Biological Assays}

The antimicrobial activities of compounds 1-4 were tested with the paper disc diffusion assay against four plant pathogenic fungi (Magnaporthe oryzae, Phomopsis asparagi, Colletotrichum truncatum, Colletotrichum gloeosporioides), three Gram-positive bacteria (Mycobacterium smegmatis $\mathrm{mc}^{2}$ 155, Bacillus subtilis PCI219 and Staphylococcus aureus ATCC 25923), and three Gram-negative bacteria (Proteusbacillus vulgaris CPCC 160013, Escherichia coli CICC 10003 and Salmonella enterica serovar Typhimurium UK-1 $\chi 8956$ ). Amphotericin B and ampicillin were used as positive controls for fungi and bacteria, respectively. The diameters of the inhibition zones were measured to describe the activity after $24 \mathrm{~h}$ of incubation at $37^{\circ} \mathrm{C}$. 
<smiles>COc1oc(C2C/C(=C\[C@@]3(C)C=C([125I])C=C(C)[C@H]3c3ccc([N+](=O)[O-])cc3)CO2)c(C)c(=O)c1C</smiles><smiles>[R]C(=O)/C(C)=C/[C@H](C)NC(=O)/C=C\C</smiles>

$3 \mathrm{R}=\mathrm{OCH}_{3}$ $4 \mathrm{R}=\mathrm{NH}_{2}$<smiles>CC(=C/C(C)=C/C(C)=C/c1ccc([N+](=O)[O-])cc1)/C=C(\C)C1COC(c2oc(C)c(C)c(=O)c2C)C1</smiles>

Figure 1. The chemical structures for compounds 1-4

\section{Results and Discussion}

\subsection{Structure Elucidation}

Compounds 1 and $\mathbf{2}$ were obtained as pale yellow oil. The molecular formulas of both $\mathbf{1}$ and $\mathbf{2}$ were determined to be $\mathrm{C}_{28} \mathrm{H}_{31} \mathrm{NO}_{6}$ with 14 degrees of unsaturation on the basis of high-resolution ESIMS $\left(\mathrm{m} / z\right.$ 955.4301 $[2 \mathrm{M}+\mathrm{H}]^{+}$and $478.2168[\mathrm{M}+\mathrm{H}]^{+}$, respectively). The ${ }^{1} \mathrm{H},{ }^{13} \mathrm{C}$ and HSQC NMR data of both 1 and 2 (Table 1, Tables S1 and S2) revealed 28 carbon signals for five methyls, a methoxyl group, two methylenes, nine methines and eleven quaternary carbons (including a carbonyl group). The NMR data of $\mathbf{2}$ were almost identical to those of spectinabilin (Table S5) [5, 11, 14]. Further analyzing the ${ }^{1} \mathrm{H}^{-1} \mathrm{H}$ COSY and HMBC correlations (Table S2) confirmed the structure of 2 to be Spectinabilin (Figure S17). Spectinabilin was initially discovered by Rinehart group in 1976 [5] with $[\alpha]_{\mathrm{D}}+60\left(c 5.0, \mathrm{CHCl}_{3}\right)$ and later by Imoto group in $2010[11]$ with $[\alpha]^{26} \mathrm{D}+60.6\left(c 5.0, \mathrm{CHCl}_{3}\right)$, while our current work reported the isolation of spectinabilin with similar spectroscopic data, but different optical rotation at $[\alpha]^{25} \mathrm{D}-40\left(c 0.1, \mathrm{CHCl}_{3}\right)$, suggesting 2 to be (-)-spectinabilin.

The HMBC and ${ }^{1} \mathrm{H}-{ }^{1} \mathrm{H}$ COSY correlations proved that compound 1 also has a 2-methoxy-3,5dimethyl- $\gamma$-pyrone moiety $(\mathrm{C}(1)$ to $\mathrm{C}(5))$, a 1,3-disubstituted furan ring $(\mathrm{C}(6)-\mathrm{C}(8 \mathrm{a}))$ and a $p$ nitrophenyl group $(\mathrm{C}(16)$ to $\mathrm{C}(21)$ ), similar to that of spectinabilin (Figure 1). The presence of a 1,3,5trimethylcyclohexa-2,4-diene moiety $(\mathrm{C}(10)-\mathrm{C}(15))$ was determined on basis of the HMBC correlations from $\mathrm{H}-\mathrm{C}(10 \mathrm{a})$ to $\mathrm{C}(10), \mathrm{C}(11)$ and $\mathrm{C}(15)$, from $\mathrm{H}-\mathrm{C}(12 \mathrm{a})$ to $\mathrm{C}(11), \mathrm{C}(12)$ and $\mathrm{C}(13)$, and from $\mathrm{H}-\mathrm{C}(14 \mathrm{a})$ to $\mathrm{C}(13), \mathrm{C}(14)$ and $\mathrm{C}(15)$. Finally, the linkage of the above four fragments were confirmed by the key HMBC correlations from $\mathrm{H}-\mathrm{C}(6)$ and $\mathrm{H}-\mathrm{C}(7)$ to $\mathrm{C}(5), \mathrm{H}-\mathrm{C}(9)$ to $\mathrm{C}(7), \mathrm{C}(8 \mathrm{a})$, $\mathrm{C}(10)$ and $\mathrm{C}(11)$, and from $\mathrm{H}-\mathrm{C}(15)$ to $\mathrm{C}(10), \mathrm{C}(16), \mathrm{C}(17)$ and $\mathrm{C}(21)$, respectively (Figure 2). Thus, the planar structure of 1 was elucidated to be 2-methoxy-3,5-dimethyl-6-(4-(2,4,6-trimethyl-4'-nitro1,2-dihydro-[1,1'-biphenyl]-2-yl)methylene)tetrahydrofuran-2-yl)-4H-pyran-4-one. The relative stereo-configurations of $\mathrm{C}-10$ and $\mathrm{C}-15$ were determined on the basis of the NOE correlation between $\mathrm{H}-\mathrm{C}(10 \mathrm{a})$ and $\mathrm{H}-\mathrm{C}(15)$ (Figure 2).

Biosynthetic studies have revealed that these nitroaryl-substituted polyene metabolites are assembled from nitrobenzoate, malonate, and methylmalonate by modular polyketide synthases followed by tailoring reactions $[5,7,15,16]$. Compound $\mathbf{1}$, as a biogenesis analogue, should have the same biosynthetic origin. The formation of the carbon-carbon bond between $C(10)$ and $C(15)$ may arise from the mechanism of carbon cation rearrangement similar to the cyclization catalyzed by terpene synthases (Figure 3). 


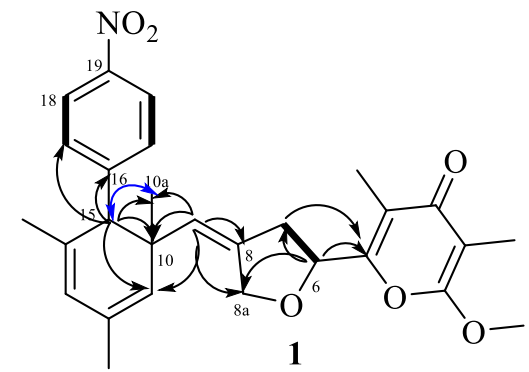

${ }^{1} \mathrm{H}^{-1} \mathrm{H}$ COSY $\longrightarrow \quad \mathrm{HMBC} \longrightarrow$

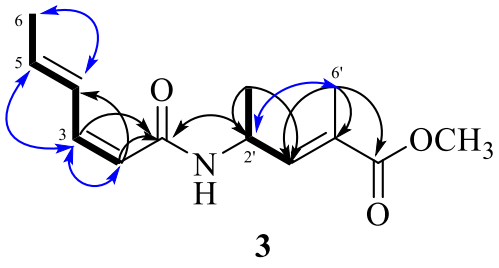

NOESY

Figure 2. The key ${ }^{1} \mathrm{H}^{-1} \mathrm{H}$ COSY, NOESY and HMBC correlations for compounds $\mathbf{1}$ and $\mathbf{3}$

Table 1. ${ }^{1} \mathrm{H}(600 \mathrm{MHz})$ and ${ }^{13} \mathrm{C}(150 \mathrm{MHz}) \mathrm{NMR}$ data of $\mathbf{1}\left(\mathrm{CD}_{3} \mathrm{OD}\right)$ and $2\left(\mathrm{C}_{5} \mathrm{D}_{5} \mathrm{~N}\right)$

\begin{tabular}{|c|c|c|c|c|}
\hline \multirow{2}{*}{ No. } & \multicolumn{2}{|l|}{1} & \multicolumn{2}{|l|}{2} \\
\hline & $\delta_{\mathrm{H}}($ mult., $J$ in $\mathrm{Hz}$ ) & $\delta_{\mathrm{C}}$ & $\delta_{\mathrm{H}}($ mult., $J$ in $\mathrm{Hz}$ ) & $\delta_{\mathrm{C}}$ \\
\hline 1 & 1 & $164.5(\mathrm{C})$ & 1 & $162.1(\mathrm{C})$ \\
\hline $1 \mathrm{a}$ & $3.94(\mathrm{~s})$ & $56.5\left(\mathrm{CH}_{3}\right)$ & $3.85(\mathrm{~s})$ & $55.3\left(\mathrm{CH}_{3}\right)$ \\
\hline 2 & I & $100.6(\mathrm{C})$ & l & $99.3(\mathrm{C})$ \\
\hline $2 \mathrm{a}$ & $1.75(\mathrm{~s})$ & $7.0\left(\mathrm{CH}_{3}\right)$ & $2.01(\mathrm{~s})$ & $7.3\left(\mathrm{CH}_{3}\right)$ \\
\hline 3 & l & $182.8(\mathrm{C})$ & l & $180.0(\mathrm{C})$ \\
\hline 4 & I & $121.0(\mathrm{C})$ & l & $120.3(\mathrm{C})$ \\
\hline $4 a$ & $1.81(\mathrm{~s})$ & $9.3\left(\mathrm{CH}_{3}\right)$ & $2.18(\mathrm{~s})$ & $9.5\left(\mathrm{CH}_{3}\right)$ \\
\hline 5 & I & $157.0(\mathrm{C})$ & I & $155.8(\mathrm{C})$ \\
\hline 6 & $4.41(\mathrm{t}, J=7.3 \mathrm{~Hz})$ & $74.4(\mathrm{CH})$ & $5.28(\mathrm{dd}, J=6.1,7.3 \mathrm{~Hz})$ & $73.5(\mathrm{CH})$ \\
\hline $7 \mathrm{a}$ & $2.49(\mathrm{dd}, J=6.6,15.0 \mathrm{~Hz})$ & $382(\mathrm{CH})$ & $3.01(\mathrm{dd}, J=6.1,14.7 \mathrm{~Hz})$ & $382\left(\mathrm{CH}^{2}\right)$ \\
\hline $7 \mathrm{~b}$ & $2.71(\mathrm{dd}, J=7.9,15.0 \mathrm{~Hz})$ & $50.2\left(\mathrm{CH}_{2}\right)$ & $3.09(\mathrm{dd}, J=7.4,14.7 \mathrm{~Hz})$ & $50.2\left(\mathrm{CH}_{2}\right)$ \\
\hline 8 & 1 & $138.1(\mathrm{C})$ & 1 & $139.7(\mathrm{C})$ \\
\hline $8 \mathrm{a}$ & $\begin{array}{l}3.54(\mathrm{~d}, J=13.1 \mathrm{~Hz}) \\
4.36(\mathrm{~d}, J=13.1 \mathrm{~Hz})\end{array}$ & $69.5\left(\mathrm{CH}_{2}\right)$ & $\begin{array}{c}5.04(\mathrm{~m}) \\
4.87(\mathrm{~d}, J=14.0 \mathrm{~Hz})\end{array}$ & $70.8(\mathrm{CH})$ \\
\hline 9 & $5.31(\mathrm{~s})$ & $129.8(\mathrm{CH})$ & $6.22(\mathrm{~s})$ & $126.9(\mathrm{CH})$ \\
\hline 10 & I & $45.2(\mathrm{C})$ & I & $134.9(\mathrm{C})$ \\
\hline $10 \mathrm{a}$ & $1.24(\mathrm{~s})$ & $29.0\left(\mathrm{CH}_{3}\right)$ & $2.10(\mathrm{~s})$ & $18.4\left(\mathrm{CH}_{3}\right)$ \\
\hline 11 & $5.25(\mathrm{~s})$ & $126.8(\mathrm{CH})$ & $6.06(\mathrm{~s})$ & $136.0(\mathrm{CH})$ \\
\hline 12 & l & $131.9(\mathrm{C})$ & I & $135.5(\mathrm{C})$ \\
\hline $12 \mathrm{a}$ & $1.82(\mathrm{~s})$ & $21.6\left(\mathrm{CH}_{3}\right)$ & $2.08(\mathrm{~s})$ & $17.8\left(\mathrm{CH}_{3}\right)$ \\
\hline 13 & $5.87(\mathrm{~s})$ & $124.7(\mathrm{CH})$ & $6.19(\mathrm{~s})$ & $135.5(\mathrm{CH})$ \\
\hline 14 & I & $137.1(\mathrm{C})$ & I & $139.9(\mathrm{C})$ \\
\hline $14 \mathrm{a}$ & $1.66(\mathrm{~s})$ & $22.8\left(\mathrm{CH}_{3}\right)$ & $2.10(\mathrm{~s})$ & $19.7\left(\mathrm{CH}_{3}\right)$ \\
\hline 15 & $3.19(\mathrm{~s})$ & $57.4(\mathrm{CH})$ & $6.62(\mathrm{~s})$ & $128.6(\mathrm{CH})$ \\
\hline 16 & l & $149.5(\mathrm{C})$ & l & $145.0(\mathrm{C})$ \\
\hline 17 & $7.39(\mathrm{~d}, J=8.5 \mathrm{~Hz})$ & $131.9(\mathrm{CH})$ & $7.51(\mathrm{~d}, J=8.8 \mathrm{~Hz})$ & $129.9(\mathrm{CH})$ \\
\hline 18 & $8.07(\mathrm{~d}, J=8.5 \mathrm{~Hz})$ & $123.5(\mathrm{CH})$ & $8.27(\mathrm{~d}, J=8.8 \mathrm{~Hz})$ & $123.7(\mathrm{CH})$ \\
\hline 19 & I & $148.4(\mathrm{C})$ & I & $146.7(\mathrm{C})$ \\
\hline 20 & $8.07(\mathrm{~d}, J=8.5 \mathrm{~Hz})$ & $123.5(\mathrm{CH})$ & $8.27(\mathrm{~d}, J=8.8 \mathrm{~Hz})$ & $123.7(\mathrm{CH})$ \\
\hline 21 & $7.39(\mathrm{~d}, J=8.5 \mathrm{~Hz})$ & $131.9(\mathrm{CH})$ & $7.51(\mathrm{~d}, J=8.8 \mathrm{~Hz})$ & $129.9(\mathrm{CH})$ \\
\hline
\end{tabular}

The molecular formula of 3 was determined to be $\mathrm{C}_{13} \mathrm{H}_{19} \mathrm{NO}_{3}$ on the basis of the HRESIMS quasi molecular ion peak at $\mathrm{m} / z 238.0702[\mathrm{M}+\mathrm{H}]^{+}\left(\right.$Calcd. for $\left.\mathrm{C}_{13} \mathrm{H}_{20} \mathrm{NO}_{3}{ }^{+}, 238.1438\right)$. The ${ }^{1} \mathrm{H},{ }^{13} \mathrm{C}$ NMR and $\mathrm{HMBC}$ data of $\mathbf{3}$ revealed 13 signals for four methyls (one oxygenated), five olefinic methines, an aliphatic methine and three quaternary $s p^{2}$ carbons (Table 2). Two fragments including a pentadiene moiety from $\mathrm{C}(2)$ to $\mathrm{C}(6)$ and a three carbon moiety of $\mathrm{C}\left(1^{\prime}\right)-\mathrm{C}\left(2^{\prime}\right)-\mathrm{C}\left(3^{\prime}\right)$ were confirmed by the ${ }^{1} \mathrm{H}-{ }^{1} \mathrm{H}$ COSY correlations. The HMBC correlations from $\mathrm{H}-\mathrm{C}(2)$ and $\mathrm{H}-\mathrm{C}(3)$ to $\mathrm{C}(1)$ indicated a 2,4hexadienoyl moiety. The planar structure was confirmed by the key HMBC correlations (Figure 2 and Table S3). The geometries of the $\mathrm{C}(2) / \mathrm{C}(3)$ and $\mathrm{C}(4) / \mathrm{C}(5)$ double bonds were determined to be $2 Z$ and 
New spectinabilin and hexadienamide derivatives

$4 E$ on the basis of the cis ${ }^{1} \mathrm{H}-{ }^{1} \mathrm{H}$ coupling constants of $J_{2,3}=11.2 \mathrm{~Hz}$ and the trans ${ }^{1} \mathrm{H}-{ }^{1} \mathrm{H}$ coupling constant of $J_{4,5}=15.0 \mathrm{~Hz}$, respectively, which was supported by the NOE correlations between $\mathrm{H}-\mathrm{C}(2)$ and $\mathrm{H}-\mathrm{C}(3), \mathrm{H}-\mathrm{C}(3)$ and $\mathrm{H}-\mathrm{C}(5)$, and $\mathrm{H}-\mathrm{C}(4)$ and $\mathrm{H}-\mathrm{C}(6)$. Additionally, the NOE between $\mathrm{H}-\mathrm{C}\left(2^{\prime}\right)$ and $\mathrm{H}-\mathrm{C}\left(6^{\prime}\right)$ determined an $E$-configuration of the $\mathrm{C}\left(3^{\prime}\right) / \mathrm{C}\left(4^{\prime}\right)$ double bond. Thus, compound 3 was elucidated to be methyl-4-((2Z,4E)-hexa-2,4-dienamido)-2-methylpent-2-enoate.<smiles>COc1oc(C2CC(=C[C@@]3(C)C=C(C)C=C(C)C3)CO2)c(C)c(=O)c1Cc1ccc([N+](=O)[O-])cc1</smiles>

Figure 3. The proposed formation of $\mathbf{1}$

The 1D NMR and HMQC data of $\mathbf{4}$ indicated the presence of three methyls, five olefinic methines, an aliphatic methine and three quaternary $s p^{2}$ carbons (Table 2), which were identical with those of sarmentosamide (Table S6) [3]. Detailed analysis of the ${ }^{1} \mathrm{H}-{ }^{1} \mathrm{H}$ COSY and HMBC spectra data of 4 (Table S4) confirmed the structure of $\mathbf{4}$ as $N$-(4'-carbamoyl-3'E-penten-2'-yl)hexa-2Z,4E-dienamide, which was supported by the ESIMS quasi molecular ion peak at $m / z 223.4[\mathrm{M}+\mathrm{H}]^{+}$.

Table 2. ${ }^{1} \mathrm{H}(400 \mathrm{MHz})$ and ${ }^{13} \mathrm{C}(100 \mathrm{MHz}) \mathrm{NMR}$ data of $\mathbf{3}\left(\mathrm{C}_{5} \mathrm{D}_{5} \mathrm{~N}\right)$ and $4\left(\mathrm{CD}_{3} \mathrm{OD}\right)$

\begin{tabular}{cllcc}
\hline \multirow{2}{*}{ No. } & \multicolumn{1}{c}{$\mathbf{3}$} & \multicolumn{4}{c}{$\mathbf{4}$} \\
\cline { 2 - 5 } (mult., $J$ in Hz) & $\delta_{\mathrm{C}}$ & $\delta_{\mathrm{H}}($ mult.,$J$ in Hz$)$ & $\delta_{\mathrm{C}}$ \\
\hline 1 & $/$ & $166.6(\mathrm{C})$ & $/$ & $168.3(\mathrm{C})$ \\
2 & $5.96(\mathrm{~d}, J=11.2 \mathrm{~Hz})$ & $120.1(\mathrm{CH})$ & $5.58(\mathrm{~d}, J=11.4 \mathrm{~Hz})$ & $119.3(\mathrm{CH})$ \\
3 & $6.49(\mathrm{dd}, J=11.2,12.8 \mathrm{~Hz})$ & $141.7(\mathrm{CH})$ & $6.43(\mathrm{t}, J=11.4 \mathrm{~Hz})$ & $142.7(\mathrm{CH})$ \\
4 & $8.18(\mathrm{dd}, J=12.8,15.0 \mathrm{~Hz})$ & $130.2(\mathrm{CH})$ & $7.43(\mathrm{dt}, J=11.4,14.8 \mathrm{~Hz})$ & $129.9(\mathrm{CH})$ \\
5 & $5.91(\mathrm{dq}, J=6.7,15.2 \mathrm{~Hz})$ & $137.8(\mathrm{CH})$ & $6.05(\mathrm{dd}, J=6.8,14.8 \mathrm{~Hz})$ & $139.1(\mathrm{CH})$ \\
6 & $1.68(\mathrm{~d}, J=6.7 \mathrm{~Hz})$ & $18.8\left(\mathrm{CH}_{3}\right)$ & $1.84(\mathrm{dd}, J=1.0,6.8 \mathrm{~Hz})$ & $18.8\left(\mathrm{CH}_{3}\right)$ \\
$1^{\prime}$ & $1.31(\mathrm{~d}, J=6.8 \mathrm{~Hz})$ & $20.7\left(\mathrm{CH}_{3}\right)$ & $1.26(\mathrm{~d}, J=6.8 \mathrm{~Hz})$ & $20.7\left(\mathrm{CH}_{3}\right)$ \\
$2^{\prime}$ & $5.22(\mathrm{~m})$ & $44.1(\mathrm{CH})$ & $4.81(\mathrm{dq}, J=6.8,8.6 \mathrm{~Hz})$ & $44.4(\mathrm{CH})$ \\
$3^{\prime}$ & $6.91(\mathrm{~d}, J=9.1 \mathrm{~Hz})$ & $144.4(\mathrm{CH})$ & $6.25(\mathrm{dd}, J=1.3,8.6 \mathrm{~Hz})$ & $139.2(\mathrm{CH})$ \\
$4^{\prime}$ & $/$ & $128.5(\mathrm{C})$ & $/$ & $132.4(\mathrm{C})$ \\
$5^{\prime}$ & $/$ & $169.1(\mathrm{C})$ & $/$ & $174.3(\mathrm{C})$ \\
$5^{\prime} \mathrm{a}$ & $3.65(\mathrm{~s})$ & $52.1\left(\mathrm{CH}_{3}\right)$ & & \\
$6^{\prime}$ & $2.10(\mathrm{~s})$ & $13.3\left(\mathrm{CH}_{3}\right)$ & $1.93(\mathrm{~d}, J=1.2 \mathrm{~Hz})$ & $13.3(\mathrm{CH})$ \\
\hline
\end{tabular}

Diverse activities of spectinabilin derivatives have been reported such as immunosuppressant activity [8,9], androgen antagonist activity [11], cytotoxic [17], nematocidal activity [14, 18] and antifungal activity [2]. In this study, compounds 1-4 showed no apparent inhibitory activities against all tested bacterial and fungal strains in agar diffusion assay at $50 \mu \mathrm{g} / \mathrm{disc}$, while amphotericin B and ampicillin as positive controls clearly showed inhibitory zones against all the tested microorganisms.

\section{Acknowledgments}

This work was supported by the National Natural Science Foundation of China (81673317, 81530091, 81602979), the Open Funding Project of State Key Laboratory of Microbial Metabolite Funding (MMLKF17-09), and the Program for Changjiang Scholars and Innovative Research Team in University (IRT_17R68). 


\section{Supporting Information}

Supporting information accompanies this paper on http://www.acgpubs.org/journal/records-ofnatural-products

\section{ORCID}

Zhiqing Zhang: 0000-0001-9525-9872

Xiaochun Zhang: 0000-0003-0669-5686

Qianjin Kang: 0000-0002-4894-0056

Chunhua Lu: $\underline{0000-0002-3261-1020}$

\section{References}

[1] Z. Q. Zhang, J. L. Zhang, R. T. Song, Z. X. Guo, H. X. Wang, J. Zhu, C. H. Lu and Y. Shen (2017). Ansavaricins A-E: five new streptovaricin derivatives from Streptomyces sp. S012, RSC Adv. 7, 56845693.

[2] Z. Q. Zhang, X. K. Wu, R. T. Song, J. L. Zhang, H. X. Wang, J. Zhu, C. H. Lu and Y. M. Shen (2017). Ansavaricins F-I, new DNA topoisomerase inhibitors produced by Streptomyces sp. S012, RSC Adv. 7, 14857-14867.

[3] S. Kitani, A. Tomio, A. Srichaisupakit, R. Daduang, B. Intra, W. Panbangred, N. Oku, Y. Igarashi and T. Nihira (2013). Sarmentosamide, a novel hexadienamide from Thai soil actinomycetes, Nat. Prod. Res. 27, 226-231.

[4] Y. Ishibashi, S. Nishiyama, Y. Shizuri and S. Yamamura (1992). Total synthesis of (+)-isoaureothin determination of the absolute-configurations of aureothin, isoaureothin and spectinabilin, Tetrahedron Lett. 33, 521-524.

[5] K. Kakinuma, C. A. Hanson and K. L. Rinehart (1976). Spectinabilin, a new nitro-containing metabolite isolated from Streptomyces spectabilis, Tetrahedron. 32, 217-222.

[6] J. Y. Ueda, J. Hashimoto, A. Nagai, T. Nakashima, H. Komaki, K. Anzai, S. Harayama, T. Doi, T. Takahashi, K. Nagasawa, T. Natsume, M. Takagi and K. Shin-ya (2007). New aureothin derivative, alloaureothin, from Streptomyces sp. MM23, J. Antibiot. 60, 321-324.

[7] F. Washizu, H. Umezawa and N. Sugiyama (1954). Chemical studies on a toxic product of Streptomyces thioluteus, aureothin, J. Antibiot. 7, 60.

[8] K. Kurosawa, K. Takahashi, N. Fujise, Y. Yamashita, N. Washida and E. Tsuda (2002). SNF4435C and D, novel immunosuppressants produced by a strain of Streptomyces spectabilis. III. Immunosuppressive efficacy, J. Antibiot. 55, 71-77.

[9] K. Takahashi, E. Tsuda and K. Kurosawa (2001). SNF4435C and D, novel immunosuppressants produced by a strain of Streptomyces spectabilis. II. Structure elucidation, J. Antibiot. 54, 548-553.

[10] K. Kurosawa, K. Takahashi and E. Tsuda (2001). SNF4435C and D, novel immunosuppressants produced by a strain of Streptomyces spectabilis. I. Taxonomy, fermentation, isolation and biological activities, $J$. Antibiot. 54, 541-547.

[11] T. Kawamura, T. Fujimaki, N. Hamanaka, K. Torii, H. Kobayashi, Y. Takahashi, M. Igarashi, N. Kinoshita, Y. Nishimura, E. Tashiro and M. Imoto (2010). Isolation and structure elucidation of a novel androgen antagonist, arabilin, produced by Streptomyces sp. MK756-CF1, J. Antibiot. 63, 601-605.

[12] Z. Latif, T. G. Hartley, M. J. Rice, R. D. Waigh and P. G. Waterman (1998). Novel and insecticidal isobutylamides from Dinosperma erythrococca, J. Nat. Prod. 61, 614-619.

[13] A. A. Shahat, S. Apers, L. Pieters and A. J. Vlietinck (2001). Isolation and complete NMR assignment of the numbing principle from Chrysanthemum morifolium, Fitoterapia. 72, 89-91.

[14] M. G. Nair, A. Chandra, D. L. Thorogod and R. M. G. Davis (1995). Nematocidal and mosquitocidal aromatic nitro-compounds produced by Streptomyces spp., Pestic. Sci. 43, 361-365.

[15] J. He and C. Hertweck (2004). Biosynthetic origin of the rare nitroaryl moiety of the polyketide antibiotic aureothin: involvement of an unprecedented $N$-oxygenase, J. Am. Chem. Soc. 126, 3694-3695.

[16] Y. S. Choi, T. W. Johannes, M. Simurdiak, Z. Shao, H. Lu and H. Zhao (2010). Cloning and heterologous expression of the spectinabilin biosynthetic gene cluster from Streptomyces spectabilis, Mol. Biosyst. 6, 336-338. 
New spectinabilin and hexadienamide derivatives

[17] S. H. Liu, M. D. Xu, H. Zhang, H. Qi, J. Zhang, C. X. Liu, J. D. Wang, W. S. Xiang and X. J. Wang (2016). New cytotoxic spectinabilin derivative from ant-associated Streptomyces sp. 1H-GS5, J. Antibiot. 69, 128-131.

[18] M. J. Liu, B. S. Hwang, C. Z. Jin, W. J. Li, D. J. Park, S. T. Seo and C. J. Kim (2019). Screening, isolation and evaluation of a nematicidal compound from actinomycetes against the pine wood nematode, Bursaphelenchus xylophilus, Pest. Manag. Sci. 75, 1585-1593.

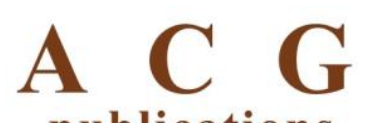

publications

(C) 2020 ACG Publications 